\title{
Retroauricular abscess from first bilateral branchial cleft sinus
}

\author{
Pedro Costa de Araujo, Julien Wen Hsieh, Sébastien Kuntzler, Elena Koonen
}

Department of Otolaryngology, Luxembourg Hospital Center, Luxembourg, Luxembourg

\section{Correspondence to} Dr Julien Wen Hsieh, hsiehjulien@gmail.com
To cite: Costa de Araujo $P$ Hsieh JW, Kuntzler S, et al. BMJ Case Rep Published online: [please include Day Month Year] doi:10.1136/ bcr-2013-009514

\section{DESCRIPTION}

A 33-year-old man presented with a left retroauricular swelling which was growing insidiously for 8 days. The patient has reported a similar episode few years ago in his right ear. Examination revealed a tract opening on a painful abscess behind the left ear (figure 1), a right retroauricular external opening without infection (figure 2), while CT scan failed to demonstrate any fistula. This suggests a left posterior abscess from bilateral first branchial cleft sinus. The abscess was drained and treated by broad-spectrum antibiotics. In case of relapse of abscess on either side, a surgical procedure will be considered.

Anomalies of the first branchial cleft typically account for less than $8 \%$ of all branchial anomalies. ${ }^{1}$ Bilateral presentations are even less reported. In embryogenesis, the branchial apparatus corresponds to the head and neck region of the embryo and is composed of branchial clefts, arches and pouches. They are derived from ectoderm, mesoderm and endoderm, respectively. The first branchial cleft later develops into external auditory meatus. When obliteration failure occurs, it forms a fistula, sinus or cyst depending on how malformation communicates with the epithelium. ${ }^{2}$ It can be diagnosed by history and physical examination alone, especially when a tract opening is present. Preoperatively, relationship between the tract and neck structures is difficult to assess even with highresolution CT scan. Permanent treatment requires surgical exploration and excision of the tract. This is complicated by the variable relationship with the facial nerve and may require superficial parotidectomy and facial nerve monitoring. ${ }^{3}$

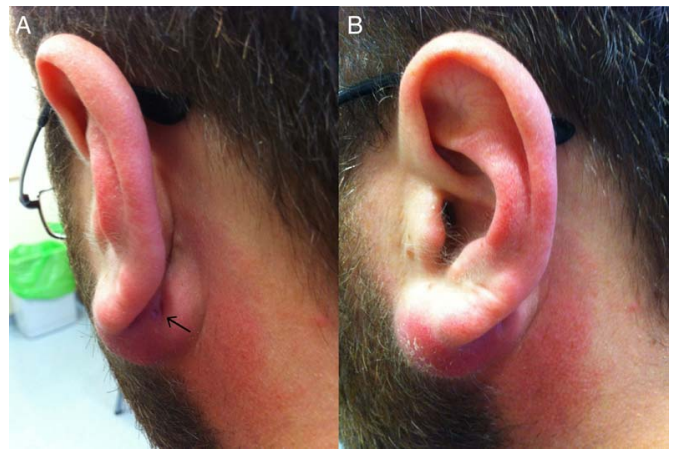

Figure 1 ( $A$ and $B)$. This figure shows a tract opening on a painful erythematous and fluctuant base behind the left ear compatible with an abscess originating from first branchial cleft anomaly.

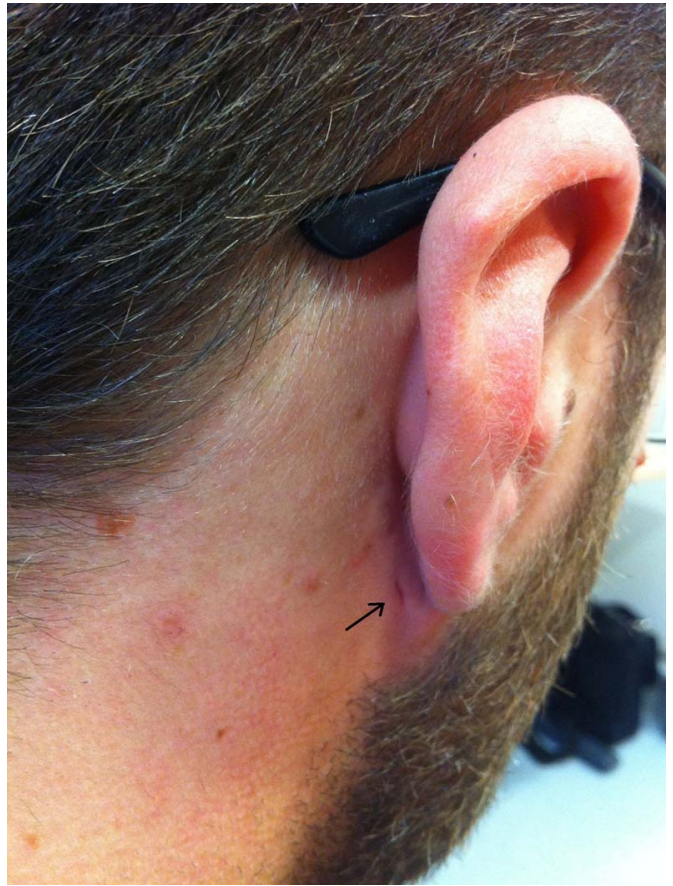

Figure 2 Examination of the right side shows a retroauricular tract opening without infection.

\section{Learning points}

First branchial cleft anomalies are rare and account for fewer than $8 \%$ of all branchial anomalies and bilateral presentations are even rarer.

- This condition can have variable presentation (abscess, cyst or fistula), localisation and relationship to the facial nerve (superficial or deep). Preoperatively, high-resolution CT scan often fails to assess relationship between tract and neck structures.

- The permanent treatment is a surgical exploration and excision of the tract after the acute infection.

Contributors PCdA, JWH, SK and EK were involved in patient care. All the authors contributed equally to the manuscript and reviewed the literature.

\section{Competing interests None.}

Patient consent Obtained.

Provenance and peer review Not commissioned; externally peer reviewed. 


\section{REFERENCES}

1 Ford GR, Balakrishnan A, Evans JN, et al. Branchial cleft and pouch anomalies. J Laryngol Otol 1992;106:137-43.
2 Olsen KD, Maragos NE, Weiland LH. First branchial cleft anomalies. Laryngoscope 1980;90:423-36.

3 Magdy EA, Ashram YA. First branchial cleft anomalies: presentation, variability and safe surgical management. Eur Arch Otorhinolaryngol 2013;270:1917-25.

Copyright 2013 BMJ Publishing Group. All rights reserved. For permission to reuse any of this content visit http://group.bmj.com/group/rights-licensing/permissions.

BMJ Case Report Fellows may re-use this article for personal use and teaching without any further permission.

Become a Fellow of BMJ Case Reports today and you can:

- Submit as many cases as you like

- Enjoy fast sympathetic peer review and rapid publication of accepted articles

- Access all the published articles

- Re-use any of the published material for personal use and teaching without further permission

For information on Institutional Fellowships contact consortiasales@bmjgroup.com

Visit casereports.bmj.com for more articles like this and to become a Fellow 